\title{
Teachers' Beliefs versus Learners' Beliefs in Grammar Teaching: Harmonizing Teaching and Learning for Adult Learners' Improved Proficiency in English
}

\author{
Iftikhar Ahmad ${ }^{1 *}$, Muhammad Sabboor Hussain², Noor Raha Mohd Radzuan ${ }^{3}$ \\ ${ }^{1}$ Department of Humanities and Administrative Sciences, Unaizah Community College, Qassim University, Saudi Arabia \\ ${ }^{2}$ English Language Research Team (ELRT), PYP, Qassim University, Saudi Arabia \\ ${ }_{3}$ Centre for Modern Languages \& Human Sciences, University Malaysia Pahang, 26600 Pekan, Pahang, Malaysia
}

Corresponding Author: Iftikhar Ahmad, E-mail: ifti12001@yahoo.com

ARTICLE INFO
Article history
Received: June 26, 2017
Accepted: July 19, 2017
Published: December 01, 2017
Volume: $6 \quad$ Issue: 7
Special Issue on Language \& Literature
Advance access: September 2017

Conflicts of interest: None Funding: None

\begin{abstract}
The study tends to explore the possible reforms to raise the proficiency level of the adult English as Foreign Language (EFL) learners. With this end in view, it investigates non-native EFL teachers' beliefs in relation to adult learners' beliefs in teaching grammar to university students in the Saudi Arabian EFL context. It finds out the harmony and disharmony between the teachers at the giving end and the taught at the receiving end to create a culture of awareness and to build a better teachinglearning environment. The study tries to fill the existing research gap as no previous research has tried to find out the solution to the problem from this angle. The main data collection tools are two five-point Likert-scale questionnaires, administered to 70 non-native EFL teachers and their 80 adult students. Teachers and learners have been selected based on stratified random sampling. Quantitative data have been analyzed using the statistical package for social sciences (SPSS). The major finding of the study are that there is discrepancy in the grammar teaching beliefs of the EFL teachers and the taught and there is a communication gap between them which result into low English proficiency. level of the EFL adult learners. Eventually, pedagogical implications of the lack of harmony between the teachers' teaching creeds and the learners' learning demands/expectations are provided for effective grammar teaching and better EFL classroom environment. The study recommends a better communicative harmony in both the stakeholders to bring reforms in adult education in EFL context.
\end{abstract}

Key words: EFL Context, Grammar Teaching, Learners' Beliefs, Learners' Proficiency, Teachers' Beliefs

\section{INTRODUCTION}

Saudi Arabian EFL context is relatively new; English language teaching and learning was introduced in this context only in 1928 (Assalahi, 2013). In the beginning, English language was introduced in schools at intermediate and secondary level and in higher education. However, a few years ago, with a refreshing realization, it was introduced in the schools at primary level as well (Rehman \& Alhaisoni, 2013). With the spread of English language education in Saudi Arabia, universities have experienced unprecedented growth in English language teachers from around the world (Javid, 2014). They include Arabic speaking EFL teachers and non-Arab EFL teachers. However, this growth in EFL teachers has not fulfilled the expectations of the Saudi ministry of education, and large gaps exist between what was expected and what is actually being produced (Liton, 2012). A growing body of research reports the low proficiency level of Saudi students in the English language (Al-Seghayer, 2011; Grami, 2010; Javid, Farooq \& Gulzar, 2012; Khan, 2011). Therefore, it is warranted not only to investigate the beliefs of English language teachers in order to ameliorate the Saudi EFL context but also to give due value to the voices of their students so that the teachers may bring positive reforms in their teaching practices in the light of valuable feedback by the adult learners.

Moreover, there is scarcity of research in the Saudi Arabian context about EFL teachers' beliefs in general and grammar teachers' beliefs in particular (Aljohani, 2012). Some studies attempted to investigate teachers' beliefs in grammar teaching (e.g. Aljohani, 2012; Assalahi, 2013; Alghanmi \& Shukri, 2016); however, no study has been carried out to understand teachers' beliefs about grammar teaching comprehensively, that is, to investigate Arab and non-Arab and male and female teachers' beliefs. Similarly, the perspective of the students, who are at the receiving end, is missing. This study attempts to bridge this gap to provide a comprehensive picture regarding EFL teachers' beliefs in grammar teaching.

Furthermore, the choice of grammar teaching for this study is based on the evidence that the use of correct grammar is mostly responsible for learners' efficient communication in the target language (Borg, 2013). It provides the learners with the structures to organize their thoughts in a 
meaningful way. The knowledge of grammar has ripple effect and influences other areas of the target language and thus, facilitates understanding of the target language (Borg, 1999). In addition, teaching/learning grammar at conscious level gives the adult EFL learners a strong sense of achievement which keeps them motivated, involved and participative in the class activities and thus facilitates the target language learning process.

Students in the Saudi Arabian EFL context study grammar for two years at university level. The courses are Essential Grammar in Use by Raymond Murphy, and a series of three books by Betty Schrampher Azar and Stacy A. Hagen. They are Basic English Grammar, Fundamentals of English Grammar and Understanding and Using English Grammar. In spite of learning English grammar for two years at university level, the proficiency level of students is reported low in the target language, especially in grammar (Grami, 2010; Khan, 2011). The tardy progress in English Language Teaching (ELT) in Saudi Arabia and the gaps in the existing literature about teacher education triggered the researchers to investigate the pedagogical belief system of grammar teachers from their own perspective and from their students' perspective in order to bring betterment in the Saudi Arabian EFL paradigm.

\section{Statement of the Problem}

Recently, research has sparked wider recognition of language teachers' mental lives (Assalahi, 2013) to improve the teaching/learning scenario. This move towards understanding their mental lives is due to the fact that teachers are decision makers who have their own pedagogical belief systems which function as filters (Borg, 2013). However, little or no attention has been paid to understanding their beliefs in general and grammar teachers' beliefs in particular, and how teachers' decisions in the classrooms are informed by their belief system (Borg, 1998). The existing research on EFL teacher beliefs in grammar teaching has been limited in several ways. A review of the literature indicates that little is known about language teachers' mental lives from their students' perspectives. Furthermore, most of the studies regarding English language teachers' beliefs are about native speaking teachers in developed countries, while most of the English language teachers are non-native speakers (Mohamed, 2006). The purpose of this study is to bridge this gap in language teacher education and understand teachers' pedagogical belief system in teaching grammar to adult learners in an EFL context and harmonize it with that of their students.

Thus, the study intends to investigate answers to the following research questions:

1. What beliefs do non-native EFL teachers hold about teaching grammar to adult learners in Saudi Arabia?

2. What are the perceptions of Saudi EFL adult learners about their teachers' grammar teaching practices?

\section{LITERATURE REVIEW}

Beliefs have been acknowledged as "notoriously difficult to define" (Mohamed, 2006, p. 18). They are so steeped in mystery that they are considered a "messy construct" (Pajares, 1992, p. 2) that can never be clearly defined. Moreover, beliefs are often used in different forms, as Borg (2013) identifies seventeen terms that have been used in language teacher beliefs' literature. This definitional confusion leads to "defining identical terms in different ways and using different terms to describe similar concepts" (Mohamed, 2006, p. 18). However, these beliefs, held consciously or unconsciously, are accepted as true by the teacher (Borg, 2001). Although beliefs are individual propositions, yet, they are constructed socially. Beliefs start going through the formation process right from the birth of the individual. They are affected and, with growing experience, change as a result of the individual's world views and professional processes. Hence, beliefs affect a teacher's decision making and filter his/her practices (Borg, 2013). Therefore, the experiences of EFL teachers and the impact of processes on them demand due research focus. Johnson (1994) suggests investigating teachers' beliefs and practices in order to improve teachers' training and classroom practices. Therefore, beliefs need to be deeply investigated, as they are among the major factors that influence educational process

Investigating language teachers' beliefs is an "established domain of research activity" (Borg, 2006, p. 46). A cursory glance at language teacher literature suggests the importance of research investigating language teacher's beliefs about language teaching and learning. However, mainstream literature in the field of Second Language (L2) education has been dominated by two types of research on teacher's beliefs. One type of studies has focused on descriptively investigating L2 teacher's beliefs, while other types of studies aim to explore comprehensively the relationship between L2 teacher's beliefs and classroom practices, with particular emphasis on grammar teaching. This study aims to descriptively investigate non-native EFL grammar teachers' beliefs.

As the teachers' experiences in teaching profession increase, when they consistently interact with the students, they form highly personalized pedagogical belief system that constraint their classroom behavior (Kagan, 1992). Apart from past experiences, there are other sources as well from which teachers derive their pedagogical beliefs. They include teaching practices, personality factors, reading, feedback from students, and principles derived from a teaching approach (Johnson, 1994). Among these belief-shaping factors, the most important one and mostly neglected one is the feedback from the students. In order to capture the complete picture of EFL teachers' belief systems, the research must focus on the issue holistically giving due importance to the feedback provided by the students.

A growing mass of research studies indicates that teachers possess a vast array of complex beliefs about pedagogical issues including beliefs about students and classroom practices (Borg, 1998, 2003, 2006; Burns, 1992). Beliefs play a pivotal role in understanding teachers' behavior and, hence the success and failure of the teaching and learning process. Beliefs are major determinants of teachers' behavior and thus guide their classroom practices (Brown \& Cooney, 1982). However, beliefs pose resistance to change too, unless they are proved unsatisfactory and, thus, the changes brought in 
them are quite deliberate (Pajares, 1992). Changing teachers' beliefs is tantamount to changing teachers' individuality, and thus they offer resistance (Kagan, 1992). Since teachers' beliefs are interconnected, therefore, it is almost difficult for a teacher to change one belief without affecting the others (Woods, 1996). Promoting research culture, which will lead the teachers to review the wrong-footed and ill-grounded beliefs, is the need of the hour.

For the teachers to abandon their well-established beliefs and practices and accommodate new ones, they need to be made aware of the lack of desired productivity of their practices. They also need to be made aware of the utility of maintaining a continuous process of personal reflection(Williams and Burden, 1997). It is only then the teachers become aware of their groundless beliefs and un-mindful routine practices. As a result, they reevaluate their beliefs and practices, redefine themselves and contribute to the much needed instructional change leading to successful teaching and raised proficiency level of all the learners in general and adult EFL learners in particular (Richards, 1996). The present study is a step forward in this direction and aims to bring awareness among EFL teachers about their existing beliefs regarding grammar teaching and how they need to modify them in the light of the beliefs of their students to make harmonized efforts to raise students' proficiency level in the target language.

\section{RESEARCH METHODOLOGY}

The research design of this study is quantitative as it is built upon the hypothesized research questions that there is a disharmony in grammar teaching/learning beliefs between the teachers and the taught which results into low proficiency level of the adult EFL learners. It is also quantitative because "the term quantitative implies the use primarily of statistics or numerical data in a study" (Strokes \& Wall, 2014, p, 129). Though the study is focused on people in action, that is, the teachers teaching grammar and the learners learning it, the quantitative research design has made it generalizable to all the teaching-learning contexts around the world where English grammar is taught, language proficiency level of the learners is an area of concern and where there is need to bring more harmony between the language teaching efforts and the learning outcomes. Following is the explanation of the research design used in the study at hand.

\section{Instruments}

Questionnaires are commonly used data collection instruments to study teachers' beliefs (Dörnyei, 2007). They can be used to collect both qualitative and quantitative data. In this study, two questionnaires were used to gather data, one for grammar teachers and the other for students. Students' questionnaire complemented that of teachers' questionnaire. The questionnaires were developed on the basis of existing literature on teachers' beliefs about grammar teaching methods, approaches and techniques. Each questionnaire contained ten items. Teachers and their students were required to respond to the items on a five point Likert scale, ranging from strongly agree to strongly disagree. Both questionnaires were divided into two sections. Section one aimed to collect demographic data from teachers and students, while section two attempted to collect teachers' beliefs about grammar teaching and students' beliefs about their teachers' actual classroom practices in grammar teaching.

The validity of the questionnaires was determined by a panel of four PhD holders. The questionnaires were modified and improved in line with their recommendations. Students' questionnaire was translated into Arabic to make it easy for the students to understand and to collect accurate data. The responses from teachers and students were coded and transferred to SPSS Ver. 14. The Cronbach's alpha coefficient for teachers' questionnaire was found to be 0.702 , while for students' questionnaire it was 0.709 that showed the high internal reliability of the tools.

Male teachers' questionnaires and boy students' questionnaires were distributed and collected by the researchers themselves, while female teachers' questionnaires and girl students' questionnaires were collected with the help of the administrators at Qassim University, Saudi Arabia, as there are cultural barriers in the way of approaching the female teachers and girl students directly in this part of the world.

\section{Respondents}

The population of this study included non-native EFL teachers teaching grammar at Qassim University, and their boy and girl students. Teachers and students were chosen through stratified random sampling. Teachers' sample was further divided into male and female and Arab and non-Arab EFL grammar teachers; 29 of them were Arab and 41 were non-Arab, while 52 were male and 18 were female teachers. Out of the 70 respondent teachers, 24 were $\mathrm{PhD}$ holders, while 46 were Masters Degree holders. Similarly, students' respondents consisted of 40 boys and 40 girls students (See Table 1).

\section{RESULTS AND DISCUSSION}

The results of the present research study are quite revealing and provide a guideline for all the stakeholders to make well-directed efforts to improve the EFL scenario and bring harmony between teaching and learning for learners' improved proficiency in English. The following table presents the perception of all categories of EFL teachers showing that

Table 1. Demographic data of respondent teachers

\begin{tabular}{lc}
\cline { 2 - 2 } Respondents & $\boldsymbol{N}(\boldsymbol{\%})$ \\
\hline Arab teachers & $29(41.4)$ \\
Non-Arab teachers & $41(58.6)$ \\
Male teachers & $52(74.3)$ \\
Female teachers & $18(25.7)$ \\
PhD holders & $24(34.3)$ \\
Master degree holders & $46(65.7)$ \\
Total & $70(100)$ \\
\hline
\end{tabular}


they put emphasis on the importance of grammar teaching to adult EFL learners:

Table 2 reflects the uniformity among all the teacher respondents in their perception about the teaching of grammar to their students. They all seem to share the conviction that grammar is an important linguistic aspect that needs to be given due importance in EFL teaching. The results of the study are consistent with the results of previous studies, like, Assalahi (2013) and Nishimuro and Borg (2013), where teachers acknowledge that grammar instruction plays a vital role in an EFL environment. Aljohani (2012) also reports that respondent teachers believe that grammar is an important component of language, and significant amount of time needs to be allotted for grammar teaching.

Table 3 shows that the Arab and Non-Arab EFL teachers have unanimity in almost all areas of grammar teaching focused on in this research. However, in the areas of focus on forms and integration of grammar with other skills, their $\mathrm{t}$-value is greater than the critical t-value which shows a difference of opinion between the two groups.

Table 4 clearly shows that Arab teachers believe that a grammar lesson should not focus on the form only whereas the Non-Arab teachers believe form to be an important aspect of grammar to be taught. There are $48.3 \%$ of Arab teachers who form the majority group as they disagree, and $13 \%$ of them strongly disagree with the statement that a grammar lesson should focus on forms; however, Non-Arab teachers are almost equally divided on the notion and $43.9 \%$ disagree, but $36.6 \%$ agree and $7.3 \%$ strongly agree with the statement. The result displays that respondent teachers are not followers of traditional grammar teaching, as focus on forms approach is equated with traditional method which entails teaching discrete linguistics structures in separate lessons in a sequence determined by the syllabus (Laufer \& Girsai, 2008). However, linguist like Sheen (2003) favours this approach and argues that focus on forms approach is unfairly stigmatized as being incompatible with the new theories of grammar teaching by linguists without reliable empirical evidence. Sheen (2003) claims that overwhelming majority of learners in different contexts owe their success to traditional methodologies. The results of the study are inconsistent with those reported by Yusal and Bardakci (2014), where $70 \%$ teachers follow focus on forms approach, maintaining that focus on forms approach is compulsory for acquiring English language, as mechanical drills and repetitions are helpful for language acquisition.

With respect to integration of grammar, majority in both groups seem to have an agreement that grammar should be integrated with other language skills. However, there is a slight difference in the percentages of the respondents for the agreement and strongly agreement slots. The result of the study regarding integration of grammar with other skills is

Table 2. A comparative analysis of the teachers' responses

\begin{tabular}{|c|c|c|c|c|c|}
\hline & & t-value & t-critical & df & Cofidence interval \\
\hline \multicolumn{6}{|c|}{ Arab teachers } \\
\hline Mean \pm SD & $3.817241 \pm 1.040799$ & 0.060077 & 2 & 68 & 0.05 \\
\hline \multicolumn{6}{|c|}{ Non-Arab teachers } \\
\hline Mean \pm SD & $3.802439 \pm 0.978516$ & & & & \\
\hline \multicolumn{6}{|c|}{ Male teachers } \\
\hline Mean \pm SD & $3.830769 \pm 1.006944$ & 0.149654 & & & 0.05 \\
\hline \multicolumn{6}{|c|}{ Female teachers } \\
\hline Mean \pm SD & $3.788889 \pm 3.788889$ & & & & \\
\hline
\end{tabular}

Table 3. Arab vs. Non-Arab EFL teachers' beliefs

\begin{tabular}{|c|c|c|c|c|c|c|}
\hline & \multicolumn{2}{|c|}{ Mean \pm SD } & \multirow[t]{2}{*}{ cal t-value } & \multirow[t]{2}{*}{ t-critical } & \multirow[t]{2}{*}{ df } & \multirow{2}{*}{$\begin{array}{c}\text { Confidence } \\
\text { interval }\end{array}$} \\
\hline & Arab teachers & Non-Arab teacher & & & & \\
\hline *PPP method & $4.206897 \pm 0.619868$ & $4.146341 \pm 0.691411$ & 0.383681 & 2 & 68 & 0.05 \\
\hline Learner centered activities & $4.137931 \pm 0.833415$ & $4.073171 \pm 0.68521$ & 0.344185 & 2 & 68 & 0.05 \\
\hline Deductive teaching & $3.37931 \pm 1.049278$ & $3.390244 \pm 1.092658$ & -0.04221 & 2 & 68 & 0.05 \\
\hline Inductive teaching & $4.206897 \pm 0.67503$ & $4.04878 \pm 0.739974$ & 0.927407 & 2 & 68 & 0.05 \\
\hline Form-focused & $2.517241 \pm 1.121883$ & $3.073171 \pm 1.05807$ & -2.0907 & 2 & 68 & 0.05 \\
\hline Function-focused & $4.172414 \pm 0.75918$ & $4.219512 \pm 0.689645$ & -0.26548 & 2 & 68 & 0.05 \\
\hline Form in text & $3.793103 \pm 1.013456$ & $4.097561 \pm 0.663509$ & -1.41716 & 2 & 68 & 0.05 \\
\hline $\begin{array}{l}\text { Integration of grammar with other } \\
\text { skills }\end{array}$ & $4.37931 \pm 0.727706$ & $3.878049 \pm 0.899864$ & 2.571055 & 2 & 68 & 0.05 \\
\hline Intensive grammar teaching & $3.172414 \pm 1.037475$ & $3.073171 \pm 1.53118$ & 0.323182 & 2 & 68 & 0.05 \\
\hline Using *AVAids in teaching grammar & $4.206897 \pm 0.559292$ & $4.04878 \pm 0.947397$ & 0.874675 & 2 & 68 & 0.05 \\
\hline
\end{tabular}

*PPP: Presentation, practice and production *AV: Audio-visual 
consistent with previous results like Ezzi's (2012) and Yusal and Bardakci's (2014). The result is also in harmony with the result reported by Underwood (2012) claiming that EFL teachers in Japan held positive beliefs about integration of grammar with communicative oriented teaching.

Table 5 shows it very clearly that for all the variables related to the teaching of grammar, both male and female teachers have uniform opinion as the calculated $t$-value for all is less than the critical t-value; therefore, it can be concluded that there is no gender-based difference in the teachers' perception of the grammar teaching. A high mean score for each variable in both groups reflects an agreement to the functionality of all the variables related to the teaching of grammar as pointed out in the survey. This finding of the study is consistent with the results of the previous studies like Aljohani (2012), Kalsoom and Akhtar (2013) and Moini (2009), who report harmony of perceptions between male and female teachers regarding grammar teaching. However, the findings are inconsistent with those reported by Estalkhi, Mohammadi, Bakshiri and Kamali (2011) regarding differences across genders in grammar teaching. They suggest that differences in respondent teachers' perceptions are due to differences in their personality traits, professional experiences and educational backgrounds.

In Table 6 , the tabulated $t$-value for each statement in the questionnaire aimed to have a comparison of the respons-es of the boy and girl EFL learners in Saudi Arabia. The Table above shows a low score, less than the critical t-value i.e. 1.99. This indicates that the boys and girls have almost the same opinion about each statement presented to them in the questionnaire. These findings eliminate the commonly held concept that boy and girl EFL learners are different in their approach to English language. They might be different in some other aspects of language teaching/learning, but when it comes to variables under the present research study, there is no remarkable difference.

As Table 7 reveals, a low mean score for all the variables, except for integration of grammar with other skills and use of teaching aids, shows a negative picture of grammar teaching by Arab teachers as is perceived by the boys in their EFL classes. It indicates that the Arab grammar teachers do not make efforts to make their teaching effective. However, they are provided with the audio visual aids and they make use of them in teaching grammar to their students. Although it is not clear whether the use of teaching aids is extensive or less, an issue which requires a deeper research probe. Moreover, they also integrate grammar with other language skills.

Table 8 displays that the boy students' responses about their Non-Arab teachers' grammar teaching practices are not very different from their views about their Arab teachers' grammar teaching practices. There can be seen a low mean score for the first seven variables. However, the boys' responses to the last three variables show that the non-Arab teachers try to integrate the grammar with the teaching of other language skills and they also make an effort to teach grammar intensively to the students given under their charge.

Table 4. Teachers' focus on forms approach and integration of grammar with other language skills

\begin{tabular}{lccccc}
\hline & \multicolumn{2}{c}{ Focus on forms } & & \multicolumn{2}{c}{ Integration of grammar with other skills } \\
\cline { 2 - 3 } \cline { 5 - 6 } & Arab teachers (\%) & Non-Arab teachers (\%) & & Arab teachers (\%) & Non-Arab teachers (\%) \\
\hline Strongly disagree & 13.7 & 0 & 0 & 3.4 & 0 \\
Disagree & 48.3 & 43.9 & 3.4 & 4.6 & 2.4 \\
Neutral & 17.2 & 12.2 & 36.6 & 48.8 & 63.4 \\
Agree & 13.8 & 7.3 & 48.8 & 19.5 \\
Strongly agree & 6.9 & &
\end{tabular}

Table 5. Male vs. Female EFL teachers' beliefs

\begin{tabular}{|c|c|c|c|c|c|c|}
\hline & \multicolumn{2}{|c|}{ Mean \pm SD } & \multirow[t]{2}{*}{ cal t-value } & \multirow[t]{2}{*}{ t-critical } & \multirow[t]{2}{*}{ df } & \multirow{2}{*}{$\begin{array}{c}\text { Confidence } \\
\text { interval }\end{array}$} \\
\hline & Male teachers & Female teachers & & & & \\
\hline PPP method & $4.134615 \pm 0.471719$ & $4.277778 \pm 0.330065$ & -0.67394 & 2 & 68 & 0.05 \\
\hline Learner centered activities & $4.096154 \pm 0.559201$ & $4.166667 \pm 0.617647$ & -0.29268 & 2 & 68 & 0.05 \\
\hline Deductive teaching & $3.403846 \pm 1.225867$ & $3.388889 \pm 1.075163$ & 0.05325 & 2 & 68 & 0.05 \\
\hline Inductive teaching & $4.076923 \pm 0.621418$ & $4.277778 \pm 0.212418$ & -0.99481 & 2 & 68 & 0.05 \\
\hline Form-focused & $2.807692 \pm 1.177979$ & $2.888889 \pm 1.281046$ & -0.28057 & 2 & 68 & 0.05 \\
\hline Function-focused & $4.211538 \pm 0.601433$ & $4.222222 \pm 0.300654$ & -0.05015 & 2 & 68 & 0.05 \\
\hline Form in text & $4.057692 \pm 0.643665$ & $3.777778 \pm 0.888889$ & 1.074951 & 2 & 68 & 0.05 \\
\hline $\begin{array}{l}\text { Integration of grammar with other } \\
\text { skills }\end{array}$ & $4.076923 \pm 0.739065$ & $4.166667 \pm 0.852941$ & -0.34455 & 2 & 68 & 0.05 \\
\hline Intensive grammar teaching & $3.269231 \pm 1.220211$ & $2.722222 \pm 1.153595$ & 1.923029 & 2 & 68 & 0.05 \\
\hline $\begin{array}{l}\text { Using AVAids in teaching } \\
\text { grammar }\end{array}$ & $4.173077 \pm 0.694947$ & $4 \pm 0.588235$ & 0.714727 & 2 & 68 & 0.05 \\
\hline
\end{tabular}


Table 6. A comparative analysis of boy and girl students' perceptions about their teachers' teaching of grammar

\begin{tabular}{cccccccc}
\multicolumn{2}{c}{ Boys } & & Girls & t-tabulated t-critical & df $\begin{array}{c}\text { Confidence } \\
\text { interval }\end{array}$ \\
Mean Variance & $\begin{array}{l}\text { Standard } \\
\text { deviation }\end{array}$ & Mean Variance & $\begin{array}{l}\text { Standard } \\
\text { deviation }\end{array}$ & & &
\end{tabular}

\begin{tabular}{|c|c|c|c|c|c|c|c|c|c|c|}
\hline PPP method & 2.025 & 0.5891 & 0.7675 & 2.075 & 5.2051 & 2.2814 & -0.1302 & 1.99 & 78 & 0.05 \\
\hline $\begin{array}{l}\text { Learner centered } \\
\text { activities }\end{array}$ & 2.675 & 1.6608 & 1.2887 & 2.7 & 9.7435 & 3.1214 & -0.0460 & 1.99 & 78 & 0.05 \\
\hline Deductive teaching & 1.8 & 0.7282 & 0.8533 & 1.775 & 4.2307 & 2.05688 & 0.0697 & 1.99 & 78 & 0.05 \\
\hline Inductive teaching & 2.1 & 0.5538 & 0.7442 & 1.95 & 4.6666 & 2.16024 & 0.4114 & 1.99 & 78 & 0.05 \\
\hline Form-focused & 2.45 & 1.6897 & 1.2999 & 2.275 & 7.1538 & 2.67466 & 0.3627 & 1.99 & 78 & 0.05 \\
\hline Function-focused & 2.275 & 0.8711 & 0.9333 & 2.35 & 6.7692 & 2.60177 & -0.1697 & 1.99 & 78 & 0.05 \\
\hline Form in text & 1.9 & 0.6051 & 0.777 & 2.15 & 5.64102 & 2.37508 & -0.6280 & 1.99 & 78 & 0.05 \\
\hline $\begin{array}{l}\text { Integration of } \\
\text { grammar with other } \\
\text { skills }\end{array}$ & 3.95 & 1.2794 & 1.1311 & 3.8 & 16.307 & 4.03827 & 0.2256 & 1.99 & 78 & 0.05 \\
\hline $\begin{array}{l}\text { Intensive grammar } \\
\text { teaching }\end{array}$ & 3.475 & 1.5891 & 1.2605 & 3.5 & 14.564 & 3.81629 & -0.0390 & 1.99 & 78 & 0.05 \\
\hline $\begin{array}{l}\text { Using AVAids in } \\
\text { teaching grammar }\end{array}$ & 4.475 & 0.7173 & 0.8469 & 4.15 & 18.564 & 4.30860 & 0.4703 & 1.99 & 78 & 0.05 \\
\hline
\end{tabular}

Table 7. Boy students' beliefs about Arab teachers

\begin{tabular}{lccc}
\hline & Mean & Variance & $\begin{array}{c}\text { Standard } \\
\text { deviation }\end{array}$ \\
\hline PPP method & 2 & 0.316447 & 0.562537 \\
Learner centered activities & 2.75 & 1.782237 & 1.335004 \\
Deductive teaching & 1.7 & 0.757895 & 0.870572 \\
Inductive teaching & 2.15 & 0.663158 & 0.814345 \\
Form-focused & 2.55 & 1.744737 & 1.320885 \\
Function-focused & 2.5 & 1.053289 & 1.026299 \\
Form in text & 1.85 & 0.347368 & 0.58938 \\
$\begin{array}{l}\text { Integration of grammar } \\
\text { with other skills }\end{array}$ & 4.1 & 0.960526 & 0.980064 \\
$\begin{array}{l}\text { Intensive grammar } \\
\text { teaching }\end{array}$ & 3.3 & 1.516447 & 1.231441 \\
$\begin{array}{l}\text { Using AVAids in teaching } \\
\text { grammar }\end{array}$ & 4.65 & 0.271711 & 0.521259 \\
\hline
\end{tabular}

Integration of grammar teaching with other language skills leads to contextualized language instruction which in turn can raise the proficiency of EFL adult learners to the desired level.

Teaching grammar structures intensively can also prove to be very useful for adult EFL learners. Teaching grammar structures intensively indicates that non-Arab teachers focus more on making the students internalize the grammatical structures (Ellis, 2006). Ellis argues that "there is little doubt now that intensive grammar lessons can be effective" (p. 94). The objective underlying intensive grammar teaching is to enable the students produce grammatical forms correctly on their own (Ur, 1996). Furthermore, they also make use of teaching aids to facilitate learning English grammar for their students.
Table 8. Boy students' beliefs about Non-Arab teachers

\begin{tabular}{lccc}
\hline & Mean & Variance & $\begin{array}{c}\text { Standard } \\
\text { deviation }\end{array}$ \\
\hline PPP method & 2.05 & 0.892763 & 0.944861 \\
Learner centered activities & 2.6 & 1.626974 & 1.275529 \\
Deductive teaching & 1.9 & 0.736842 & 0.858395 \\
Inductive teaching & 2.05 & 0.473684 & 0.688247 \\
Form-focused & 2.35 & 1.723684 & 1.312892 \\
Function-focused & 2.05 & 0.734868 & 0.857245 \\
Form in text & 1.95 & 0.894737 & 0.945905 \\
Integration of grammar & 3.8 & 1.665789 & 1.290655 \\
with other skills & & & \\
$\begin{array}{l}\text { Intensive grammar } \\
\text { teaching }\end{array}$ & 3.65 & 1.745395 & 1.321134 \\
$\begin{array}{l}\text { Using AVAids in teaching } \\
\text { grammar }\end{array}$ & 4.3 & 1.200658 & 1.095745 \\
\hline & & & \\
\hline
\end{tabular}

In Table 9, the low t-value for each variable (lower than the critical value 2.021) indicates that the boys do not find much difference between their Arab teachers' and Non-Arab teachers' grammar teaching practices.

The results in Table 10 show that the girls are not very satisfied with their Arab teachers teaching grammar to them. The table shows a low mean score for the first seven variables which presents a negative picture. However, the higher mean score for last three variables reflect that their Arab teachers integrate grammar in the teaching of other language skills, use AV aids and give their students intensive grammar practice as well.

Table 11 displays that girl EFL learners view their non-Arab teachers' grammar teaching practices a little more positively and we find higher mean scores for learner-cen- 
Table 9. A comparative analysis of boy students' perceptions about their Arab vs. non-Arab teachers' teaching grammar

\begin{tabular}{|c|c|c|c|c|c|c|c|c|c|c|}
\hline & \multicolumn{3}{|c|}{$\begin{array}{c}\text { Perceptions about Arab } \\
\text { teachers }\end{array}$} & \multicolumn{3}{|c|}{$\begin{array}{l}\text { Perceptions about } \\
\text { non-Arab teachers }\end{array}$} & \multirow[t]{2}{*}{ t-tabulated } & \multirow[t]{2}{*}{ t-critical } & \multirow[t]{2}{*}{ df } & \multirow[t]{2}{*}{$\begin{array}{l}\text { Confidence } \\
\text { interval }\end{array}$} \\
\hline & Mean & Variance & $\begin{array}{l}\text { Standard } \\
\text { deviation }\end{array}$ & Mean & Variance & $\begin{array}{l}\text { Standard } \\
\text { deviation }\end{array}$ & & & & \\
\hline PPP method & 2 & 0.316447 & 0.562537 & 2.05 & 0.892763 & 0.944861 & -0.20335 & 2.021 & 38 & 0.05 \\
\hline $\begin{array}{l}\text { Learner centered } \\
\text { activities }\end{array}$ & 2.75 & 1.782237 & 1.335004 & 2.6 & 1.626974 & 1.275529 & 0.363312 & 2.021 & 38 & 0.05 \\
\hline Deductive teaching & 1.7 & 0.757895 & 0.870572 & 1.9 & 0.736842 & 0.858395 & -0.73158 & 2.021 & 38 & 0.05 \\
\hline Inductive teaching & 2.15 & 0.663158 & 0.814345 & 2.05 & 0.473684 & 0.688247 & 0.419435 & 2.021 & 38 & 0.05 \\
\hline Form-focused & 2.55 & 1.744737 & 1.320885 & 2.35 & 1.723684 & 1.312892 & 0.480263 & 2.021 & 38 & 0.05 \\
\hline Function-focused & 2.5 & 1.053289 & 1.026299 & 2.05 & 0.734868 & 0.857245 & 1.504959 & 2.021 & 38 & 0.05 \\
\hline Form in text & 1.85 & 0.347368 & 0.58938 & 1.95 & 0.894737 & 0.945905 & -0.40127 & 2.021 & 38 & 0.05 \\
\hline $\begin{array}{l}\text { Integration of grammar } \\
\text { with other kills }\end{array}$ & 4.1 & 0.960526 & 0.980064 & 3.8 & 1.665789 & 1.290655 & 0.827871 & 2.021 & 38 & 0.05 \\
\hline $\begin{array}{l}\text { Intensive grammar } \\
\text { teaching }\end{array}$ & 3.3 & 1.516447 & 1.231441 & 3.65 & 1.745395 & 1.321134 & -0.86667 & 2.021 & 38 & 0.05 \\
\hline $\begin{array}{l}\text { Using AVAids in } \\
\text { teaching grammar }\end{array}$ & 4.65 & 0.271711 & 0.521259 & 4.3 & 1.200658 & 1.095745 & 1.289956 & 2.021 & 38 & 0.05 \\
\hline
\end{tabular}

Table 10. Girl students' beliefs about Arab teachers' grammar teaching practices

\begin{tabular}{lccc}
\hline & Mean & Variance & $\begin{array}{c}\text { Standrad } \\
\text { deviation }\end{array}$ \\
\hline PPP method & 2.3 & 6.526316 & 2.554665 \\
Learner centered activities & 2.15 & 7.210526 & 2.685242 \\
Deductive teaching & 1.4 & 2.421053 & 1.555973 \\
Inductive teaching & 1.6 & 3.052632 & 1.747178 \\
Form-focused & 2.7 & 10.21053 & 3.195391 \\
Function-focused & 2.45 & 7.526316 & 2.743413 \\
Form in text & 1.8 & 3.684211 & 1.91943 \\
$\begin{array}{l}\text { Integration of grammar } \\
\text { with other skills }\end{array}$ & 3.75 & 16.68421 & 4.084631 \\
$\begin{array}{l}\text { Intensive grammar } \\
\text { teaching }\end{array}$ & 3.25 & 13.42105 & 3.663475 \\
$\begin{array}{l}\text { Using AVAids in teaching } \\
\text { grammar }\end{array}$ & 4.25 & 19.73684 & 4.442617 \\
\hline
\end{tabular}

tered activities, integration of grammar with other skills, intensive grammar teaching and using AV Aids in teaching grammar. However, for the rest of the variables, the mean scores are low.

Table 12 indicates a comparison of girl students' perception of their Arab and non-Arab teachers' grammar teaching practices. It shows that there is not much difference perceived by the girls in the teaching practices of their Arab and non- Arab teachers. The t-values for all the variables are lower than the critical value i.e. 2.021. However, the results indicate that non-Arab teachers employ more learner-centered activities than their Arab colleagues, as the difference in mean scores for this variable indicates.

Table 13 shows that there is no significant difference between the perceptions of girls and boys respondents about
Table 11. Girl students' beliefs about Non-Arab teachers' grammar teaching practices

\begin{tabular}{lccc}
\hline & Mean & Variance & $\begin{array}{c}\text { Standard } \\
\text { deviation }\end{array}$ \\
\hline PPP method & 1.85 & 4.157895 & 2.039092 \\
Learner centered activities & 3.25 & 12.78947 & 3.576237 \\
Deductive teaching & 2.15 & 6.263158 & 2.50263 \\
Inductive teaching & 2.3 & 6.526316 & 2.554665 \\
Form-focused & 1.85 & 4.473684 & 2.115109 \\
Function-focused & 2.25 & 6.368421 & 2.523573 \\
Form in text & 2.5 & 7.894737 & 2.809757 \\
$\begin{array}{l}\text { Integration of grammar } \\
\text { with other skills }\end{array}$ & 3.85 & 16.78947 & 4.097496 \\
$\begin{array}{l}\text { Intensive grammar } \\
\text { teaching }\end{array}$ & 3.75 & 16.47368 & 4.058779 \\
$\begin{array}{l}\text { Using AVAids in teaching } \\
\text { grammar }\end{array}$ & 4.05 & 18.36842 & 4.28584 \\
\hline
\end{tabular}

the grammar teaching practices of their Arab teachers. The calculated t-value in each case is lower than the critical t-value.

Table 14 reveals almost the same results as those in Table 13. The boys and girls do not differ in their perception of the grammar teaching practices of their non-Arab teachers.

Table 15 reflects the differences between the perceptions of the teachers about their grammar teaching practices and their students' perceptions about teachers' actual grammar teaching practices. For four variables, that is, focus on forms, integration of grammar with other skills, intensive grammar teaching and using AV Aids in teaching grammar, both groups (teachers and students) have been found to have 
Table 12. A comparative analysis of girl students' perceptions about their Arab vs. Non- Arab teachers' teaching grammar

\begin{tabular}{|c|c|c|c|c|c|c|c|c|c|c|}
\hline & \multicolumn{3}{|c|}{$\begin{array}{c}\text { Perceptions about Arab } \\
\text { teachers }\end{array}$} & \multicolumn{3}{|c|}{$\begin{array}{l}\text { Perceptions about } \\
\text { Non-Arab teachers }\end{array}$} & \multirow[t]{2}{*}{ t-tabulated } & \multirow[t]{2}{*}{ t-critical } & \multirow{2}{*}{\multicolumn{2}{|c|}{$\begin{array}{c}\text { Df Confidence } \\
\text { interval }\end{array}$}} \\
\hline & Mean & Variance & $\begin{array}{l}\text { Standard } \\
\text { deviation }\end{array}$ & Mean & Variance & $\begin{array}{l}\text { Standard } \\
\text { deviation }\end{array}$ & & & & \\
\hline PPP method & 2.3 & 6.526316 & 2.554665 & 1.85 & 4.157895 & 2.039092 & 0.615682 & 2.021 & 38 & 0.05 \\
\hline Learner centered activities & 2.15 & 7.210526 & 2.685242 & 3.25 & 12.78947 & 3.576237 & -1.1 & 2.021 & 38 & 0.05 \\
\hline Deductive teaching & 1.4 & 2.421053 & 1.555973 & 2.15 & 6.263158 & 2.50263 & -1.13818 & 2.021 & 38 & 0.05 \\
\hline Inductive teaching & 1.6 & 3.052632 & 1.747178 & 2.3 & 6.526316 & 2.554665 & -1.01147 & 2.021 & 38 & 0.05 \\
\hline Form-focused & 2.7 & 10.21053 & 3.195391 & 1.85 & 4.473684 & 2.115109 & 0.991993 & 2.021 & 38 & 0.05 \\
\hline Function-focused & 2.45 & 7.526316 & 2.743413 & 2.25 & 6.368421 & 2.523573 & 0.239949 & 2.021 & 38 & 0.05 \\
\hline Form in text & 1.8 & 3.684211 & 1.91943 & 2.5 & 7.894737 & 2.809757 & -0.91998 & 2.021 & 38 & 0.05 \\
\hline $\begin{array}{l}\text { Integration of grammar with } \\
\text { other skills }\end{array}$ & 3.75 & 16.68421 & 4.084631 & 3.85 & 16.78947 & 4.097496 & -0.0773 & 2.021 & 38 & 0.05 \\
\hline Intensive grammar teaching & 3.25 & 13.42105 & 3.663475 & 3.75 & 16.47368 & 4.058779 & -0.40897 & 2.021 & 38 & 0.05 \\
\hline $\begin{array}{l}\text { Using avaids in teaching } \\
\text { grammar }\end{array}$ & 4.25 & 19.73684 & 4.442617 & 4.05 & 18.36842 & 4.28584 & 0.144895 & 2.021 & 38 & 0.05 \\
\hline
\end{tabular}

Table 13. A comparative analysis of boy and girl student's perceptions about their Arab teachers' grammar teaching

\begin{tabular}{|c|c|c|c|c|c|c|c|c|c|c|}
\hline & \multicolumn{3}{|c|}{ Boys } & \multicolumn{3}{|c|}{ Girls } & \multirow[t]{2}{*}{ t-tabulated } & \multirow[t]{2}{*}{ t-critical } & \multirow{2}{*}{ df } & \multirow{2}{*}{$\begin{array}{l}\text { Confidence } \\
\text { inetrval }\end{array}$} \\
\hline & Mean & Variance & $\begin{array}{l}\text { Standard } \\
\text { deviation }\end{array}$ & Mean & Variance & $\begin{array}{l}\text { Standard } \\
\text { deviation }\end{array}$ & & & & \\
\hline PPP method & 2 & 0.316447 & 0.562537 & 2.3 & 6.526316 & 2.554665 & -0.51289 & 2.021 & 38 & 0.05 \\
\hline Learner centered activities & 2.75 & 1.782237 & 1.335004 & 2.15 & 7.210526 & 2.685242 & 0.894787 & 2.021 & 38 & 0.05 \\
\hline Deductive teaching & 1.7 & 0.757895 & 0.870572 & 1.4 & 2.421053 & 1.555973 & 0.752479 & 2.021 & 38 & 0.05 \\
\hline Inductive teaching & 2.15 & 0.663158 & 0.814345 & 1.6 & 3.052632 & 1.747178 & 1.276004 & 2.021 & 38 & 0.05 \\
\hline Form-focused & 2.55 & 1.744737 & 1.320885 & 2.7 & 10.21053 & 3.195391 & -0.19401 & 2.021 & 38 & 0.05 \\
\hline Function-focused & 2.5 & 1.053289 & 1.026299 & 2.45 & 7.526316 & 2.743413 & 0.07634 & 2.021 & 38 & 0.05 \\
\hline Form in text & 1.85 & 0.347368 & 0.58938 & 1.8 & 3.684211 & 1.91943 & 0.111365 & 2.021 & 38 & 0.05 \\
\hline $\begin{array}{l}\text { Integration of grammar with } \\
\text { other skills }\end{array}$ & 4.1 & 0.960526 & 0.980064 & 3.75 & 16.68421 & 4.084631 & 0.372628 & 2.021 & 38 & 0.05 \\
\hline Intensive grammar teaching & 3.3 & 1.516447 & 1.231441 & 3.25 & 13.42105 & 3.663475 & 0.057856 & 2.021 & 38 & 0.05 \\
\hline $\begin{array}{l}\text { Using avaids in teaching } \\
\text { grammar }\end{array}$ & 4.65 & 0.271711 & 0.521259 & 4.25 & 19.73684 & 4.442617 & 0.399915 & 2.021 & 38 & 0.05 \\
\hline
\end{tabular}

almost the same opinion; hence, their calculated t-value is lower than the critical t-value i.e. 1.984. However, there are great differences found in the perceptions of teachers and their students about the other variables which are PPP approach (calculated t-value 3.749641), learner-centered activities (calculated t-value 2.330917), deductive teaching (calculated t-value 3.307371), inductive teaching (calculated t-value 3.736145), focus on function (calculated t-value 3.223577) and noticing technique i.e. Form in Text (calculated t-value 3.554258).

The difference in the perceptions of the teachers and the taught on the variables under study is quite crucial and demands close attention. Therefore, there is a need to see in detail how the EFL teachers and the EFL adult learners differ in their perceptions of these variables. The following figures followed by thematic and qualitative analysis elaborate these differences in detail:
Figure 1 clearly shows a contrast between teachers' and students' beliefs regarding teaching grammar through presentation, practice and production method. The teachers, more than $90 \%$ of them, approve of following all the three stages of a lesson; however, the students do not seem to agree with their teachers. More than $90 \%$ of the students maintain that their teachers do not teach them grammar following all the three stages distinctly. It implies that majority of the teachers may stop at the first two stages only, that is, presentation and practice, without providing the students with any opportunity to go to the production stage. It further implies that teachers are text-specific and present the grammatical structures given in the text book, and only practice with the students the exercises given in the prescribed text. Teachers do not encourage the students to produce the language of their own to make them independent learners. The result of the study reveals that the classrooms in Saudi Ara- 
Table 14. A comparative analysis of boy and girl students' perceptions about their Non-Arab teachers' grammar teaching

\begin{tabular}{|c|c|c|c|c|c|c|c|c|c|c|}
\hline & \multicolumn{3}{|c|}{ Boys } & \multicolumn{3}{|c|}{ Girls } & \multirow[t]{2}{*}{ t-tabulated } & \multirow[t]{2}{*}{ t-critical } & \multirow[t]{2}{*}{ df } & \multirow{2}{*}{$\begin{array}{l}\text { Confidence } \\
\text { interval }\end{array}$} \\
\hline & Mean & Variance & $\begin{array}{l}\text { Standard } \\
\text { deviation }\end{array}$ & Mean & Variance & $\begin{array}{l}\text { Standard } \\
\text { deviation }\end{array}$ & & & & \\
\hline PPP method & 2.05 & 0.892763 & 0.944861 & 1.85 & 4.157895 & 2.039092 & 0.397989 & 2.021 & 38 & 0.05 \\
\hline Learner centered activities & 2.6 & 1.626974 & 1.275529 & 3.25 & 12.78947 & 3.576237 & -0.7656 & 2.021 & 38 & 0.05 \\
\hline Deductive teaching & 1.9 & 0.736842 & 0.858395 & 2.15 & 6.263158 & 2.50263 & -0.42258 & 2.021 & 38 & 0.05 \\
\hline Inductive teaching & 2.05 & 0.473684 & 0.688247 & 2.3 & 6.526316 & 2.554665 & -0.42258 & 2.021 & 38 & 0.05 \\
\hline Form-focused & 2.35 & 1.723684 & 1.312892 & 1.85 & 4.473684 & 2.115109 & 0.898217 & 2.021 & 38 & 0.05 \\
\hline Function-focused & 2.05 & 0.734868 & 0.857245 & 2.25 & 6.368421 & 2.523573 & -0.33559 & 2.021 & 38 & 0.05 \\
\hline Form in text & 1.95 & 0.894737 & 0.945905 & 2.5 & 7.894737 & 2.809757 & -0.82965 & 2.021 & 38 & 0.05 \\
\hline $\begin{array}{l}\text { Integration of grammar with } \\
\text { other skills }\end{array}$ & 3.8 & 1.665789 & 1.290655 & 3.85 & 16.78947 & 4.097496 & -0.05205 & 2.021 & 38 & 0.05 \\
\hline Intensive grammar teaching & 3.65 & 1.745395 & 1.321134 & 3.75 & 16.47368 & 4.058779 & -0.10477 & 2.021 & 38 & 0.05 \\
\hline $\begin{array}{l}\text { Using avaids in teaching } \\
\text { grammar }\end{array}$ & 4.3 & 1.200658 & 1.095745 & 4.05 & 18.36842 & 4.28584 & 0.252738 & 2.021 & 38 & 0.05 \\
\hline
\end{tabular}

Table 15. A comparative analysis of teachers' and students' perceptions about teachers' grammar teaching practices

\begin{tabular}{|c|c|c|c|c|c|c|c|c|}
\hline & \multicolumn{2}{|c|}{ Teachers } & \multicolumn{2}{|c|}{ Students } & \multirow[t]{2}{*}{ cal t-value } & \multirow[t]{2}{*}{ t-critical } & \multirow[t]{2}{*}{ df } & \multirow{2}{*}{$\begin{array}{l}\text { Confidence } \\
\text { interval }\end{array}$} \\
\hline & Mean & $\begin{array}{l}\text { Standard } \\
\text { deviation }\end{array}$ & Mean & $\begin{array}{l}\text { Standard } \\
\text { deviation }\end{array}$ & & & & \\
\hline PPP method & 4.171429 & 4.252876 & 2.05 & 2.221871 & 3.749641 & 1.984 & 148 & 0.05 \\
\hline Learner centered activities & 4.1 & 4.196272 & 2.6875 & 3.041901 & 2.330917 & 1.984 & 148 & 0.05 \\
\hline Deductive teaching & 3.385714 & 3.57325 & 1.7875 & 2.022031 & 3.307371 & 1.984 & 148 & 0.05 \\
\hline Inductive teaching & 4.114286 & 4.204897 & 2.025 & 2.1932 & 3.736145 & 1.984 & 148 & 0.05 \\
\hline Form-focused & 2.828571 & 3.050303 & 2.3625 & 2.721225 & 0.981513 & 1.984 & 148 & 0.05 \\
\hline Function-focused & 4.2 & 4.290198 & 2.3125 & 2.528321 & 3.223577 & 1.984 & 148 & 0.05 \\
\hline Form in text & 3.971429 & 4.086031 & 2.025 & 2.216166 & 3.554258 & 1.984 & 148 & 0.05 \\
\hline $\begin{array}{l}\text { Integration of grammar with } \\
\text { other skills }\end{array}$ & 4.085714 & 4.204897 & 3.875 & 4.072134 & 0.310726 & 1.984 & 148 & 0.05 \\
\hline Intensive grammar teaching & 3.114286 & 3.323173 & 3.4875 & 3.753479 & -0.6459 & 1.984 & 148 & 0.05 \\
\hline $\begin{array}{l}\text { Using avaids in teaching } \\
\text { grammar }\end{array}$ & 4.114286 & 4.222095 & 4.3125 & 4.43376 & -0.28021 & 1.984 & 148 & 0.05 \\
\hline
\end{tabular}

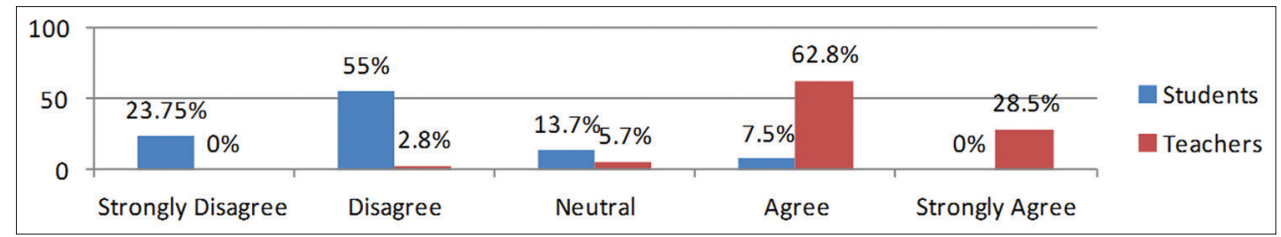

Figure 1. PPP method of grammar teaching

bia are teacher-centered and traditional methodology is very much favoured by EFL teachers, as "PPP model of grammar teaching... assumes an intensive focus on specific grammatical structures" (Ellis, 2006, p. 93). The results of the study are in line with the results reported by Nishimuro and Borg (2013) where overwhelming majority of the teachers spent their time in presenting grammar lessons in decontextualized sentences, without any planned activities to give sufficient practice of the grammatical structures to their students. Respondent teachers stated that lack of time was the reason due to which they were not able to involve students in commu- nicative activities. Nishimuro and Borg (2013) maintain that such attitude is rooted in the belief that form of grammar needs to be mastered first before its use can be learned, acquired or internalized. However, they argue that this position is contrary to the view that contextualized use of grammar is beneficial to learning which leads the learners to create links between form and meaning.

However, PPP approach of grammar teaching entails the logic that explicit knowledge of grammatical rules will transform into implicit knowledge with enough practice (De Keyser, 1998). The result indicates that since Saudi Arabian 
context is EFL, therefore, teachers practice PPP grammar teaching approach to strengthen students' grammatical base. The result further indicates that writing skill of students is focused more than their speaking skill, revealing the importance of students' demands for passing university examination, where students' grammatical knowledge is checked rather than their oral communication. The result also shows that classrooms in Saudi Arabia are teacher-centered and students are passive learners. Students concentrate on learning rules only, without practicing them in communicative activities. It further implies that rote-learning is appreciated, as parroting rules of grammar is needed during examinations.

Figure 2 shows that the majority of teachers (more than $80 \%$ of them) show their agreement on the importance of students involving activities in teaching of grammar and endorse the statement presented to them in the questionnaire; whereas the students show a different picture. There are few students, $33.75 \%$, who find such learner-centered tasks like role play and problem solving being implemented in their classes. However, almost $55 \%$ of the student respondents think otherwise and disagree with the statement. The findings imply that respondent teachers are convinced of the im-portance and utility of communicative activities; however, practically, most of them are not able to follow such activ-ities. The findings are in line with the findings reported by Nishimuro and Borg (2013) where respondent teachers did not employ communicative activities and maintained that these activities were "absolutely necessary but physically impossible because time [was] limited" (p. 37)The findings of the study in terms of students' perceptions about teachers' use of task-based grammar teaching are inconsistent with the findings of Wilhelm and Pei (2008) where respondent students perceived that communicative activities were widely used by university EFL teachers. Similarly, the students' results also imply that their classrooms were teacher dominated as teacher talking time was more than students', and students got less time to practice communicative activities.

The result in Figure 3 shows differences of opinions between EFL teachers and their students. However, teach- ers are almost equally divided in their opinion about deductive method of teaching grammar. It implies that EFL teachers in the Saudi Arabian context follow both kinds of grammar teaching methodology, deductive as well as inductive, depending on the proficiency level of the students and the nature of activities. The result of the study is inconsistent with the result by Aljohani (2012) where majority of the teachers believed that providing examples to teach rules was better than just prescribing the rules. However, the findings are consistent with the findings by Hos and Kekec (2014) where majority of the teachers believed that both deductive and inductive grammar teaching methods should be utilized depending on the circumstances. The findings revel that students' perceptions are different from their teachers', and more than $80 \%$ of them show a disagreement.

In Figure 4, there is seen a clear difference in perception of students and that of teachers. The teachers show their awareness about the importance of inductive teaching of grammar, and more than $85 \%$ of them agree with the statement. This finding is in line with that reported by Chowdhury (2014), who discovered that EFL teachers in Saudi Arabia mostly used inductive grammar teaching approach in their classes. However, the findings are inconsistent with those of Ezzi's (2012) who found that most of the teachers did not make the students infer rules from examples. The data also reveal that students do not agree with the statement and do not find their teachers practicing inductive teaching of grammar. It may be implied from the findings that teachers believe in this innovative strategy to make the students infer rules from examples, but the weak proficiency level of the students in English grammar makes them teach rules first, followed by examples

Figure 5 shows a clear discrepancy between what the teachers believe should be focused on in a grammar class and how their practices in this regard are viewed by their students. The majority of the teachers - more than $90 \%-$ believe that a grammar lesson should be function-focused and the teachers must draw his/her students' attention to meaning in context. These findings are consistent with the

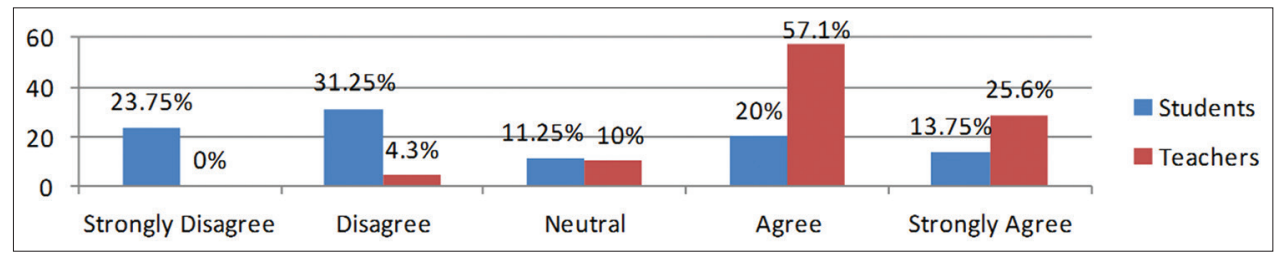

Figure 2. Learner-centered activities

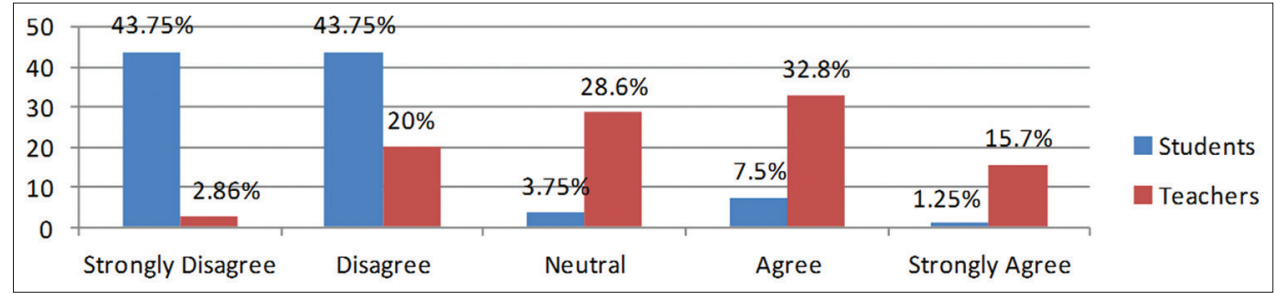

Figure 3. Deductive grammar teaching 
findings of Aljohani (2012) where respondent teachers believed that grammar was best taught in meaningful context. However, the findings are inconsistent with the finding of Assalahi (2013) where teachers believed in following forms-focused approach. However, the students report quite a different scenario. More than $80 \%$ of the students do not find their grammar teachers practicing function-focused approach in their classes. The result implies that teachers may be theoretically convinced of the importance of function-focused approach, but practically they may not be able to follow it, as mere exposure to language with no attention to grammar results in fossilization of grammar and eventually poor language production (Yusal \& Bardaki, 2014).

Figure 6 indicates that majority of the teachers believe that a good way to teach grammar is to draw students' attention to the grammar form as it arises in the text. In other words, the primary focus of the grammar lesson should be on function, and the students should be taught only those grammar items that are part of the text and that too should be explained as they appear in the context. This result is consistent with the finding by Boroujeni (2012) where teachers fovoured noticing technique and believed that this approach is completely student-centered and they can somehow control the grammatical form to be taught. However, the students report otherwise. More than $75 \%$ of the students disagree that their teachers teach them the grammar items as they appear in the text.

\section{CONCLUSION}

This study was an attempt to investigate non-native EFL teachers' beliefs about grammar teaching in relation to their adult learners' beliefs to find out possible reforms to address tardy progress in ELT in the Saudi Arabian context. In consistent with the findings of previous research studies (Like, Borg, 2003, 2006), this study indicates that teachers possess a vast array of complex pedagogical beliefs about grammar teaching. Given the findings of this study, the study reveals that the beliefs of non-native EFL teachers are mostly not aligned with their students' perceptions about their teachers' grammar teaching practices.

The teachers surveyed were found to be quite paradoxical in their perceptions. On the one hand, their thoughts and beliefs tended to be more in line with learner-centered and communicative approaches with regards to grammar teaching. On the other hand, they also believed in meaning-impoverished PPP approach (Skehan, 1998), and focusing only on form-focused grammar teaching. PPP approach of grammar teaching is considered ineffective in the Saudi Arabian context because of the students' lacking in the basic grammatical structures (Aljohani, 2012). Most of the learners in Saudi Arabian EFL context are not informed of the form and function unit of the English grammar (Khan, 2011), thus creating confusion in them in dealing with grammar exercises, which develops aversion in them to the English language. Resultantly, "English grammar teaching has not so far been a soothing balm but a seemingly impass-

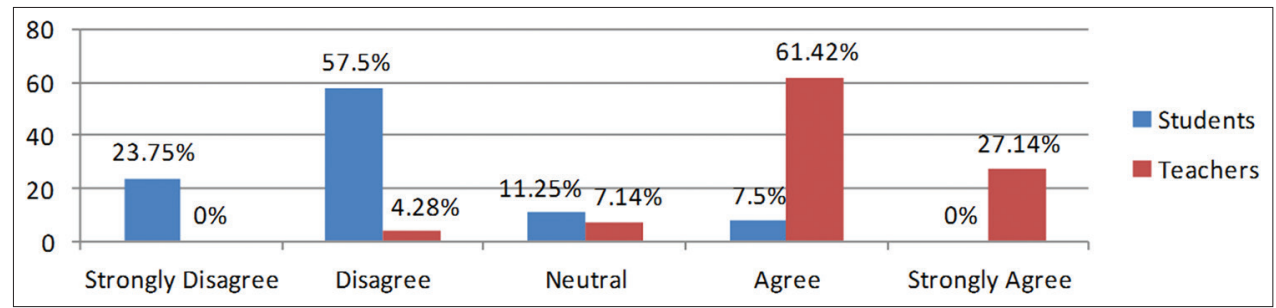

Figure 4. Inductive grammar teaching

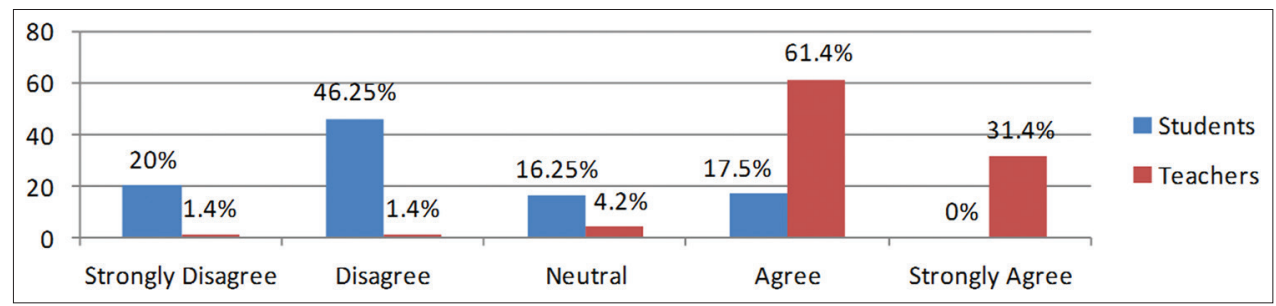

Figure 5. Focus on function approach

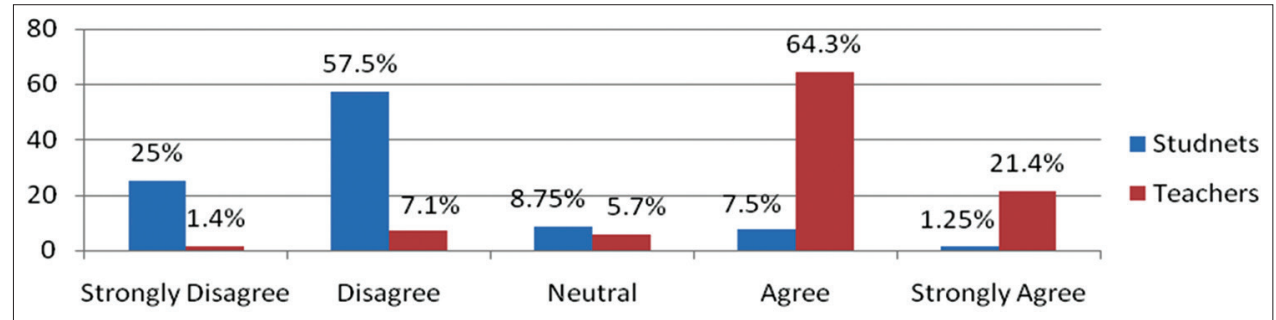

Figure 6. Noticing technique (form in text) 
able barrier to the [adult] learners" in Saudi Arabia (Chowdhry, 2014, p. 6).

However, teachers understand the learning requirement of their students, as majority of the teachers believed that both inductive and deductive teaching should be employed in grammar classes depending on the circumstances. It implies that some adult learners may benefit from inferring the rules while others may learn better if they are provided with explicit presentation of the rules and then examples. Furthermore, majority of the teachers also integrate grammar with other language skills, along with using audio visual aids to facilitate learning English grammar for their students.

The results of the study provide us a peep into the English grammar classrooms in Saudi Arabia, where teachers and their students mostly look into different directions, resulting into low proficiency level of the students. The findings lend support to the claim forwarded by previous studies (Like, Chowdhry, 2014; Grami, 2010; Khan, 2011) that EFL teachers in Saudi Arabia follow traditional grammar teaching approaches, with little or no room for innovative strategies. The results maintain that all respondent groups, Arab, non-Arab, male and female teachers are mostly similar in their approaches. The study does not find any statistically significant difference in their grammar teaching approaches. Similarly, boy and girl students are also unanimous in their opinions/perceptions about their teachers' grammar teaching approaches.

This study makes a contribution to the field as its methodology offers an in-depth understanding of what the reported beliefs of the teachers are, and how their students perceive them, showing the actual practices of the teachers, that are mostly not harmonized with their beliefs. According to the findings of this study, some general implications can be offered for a better grammar teaching and learning process. The study suggests continuous professional development for teachers to make them aware of the innovative techniques in EFL grammar teaching. The study may bring awareness among EFL grammar teachers to contemplate on the paradoxes in their belief system. The study also suggests a close collaboration between teachers and their students to bridge the gap between students' expectations, requirements and demands and teachers' classroom practices, thus harmonising the beliefs of the teachers and the taught. The study further suggests revisiting the current examination system, which encourages rote learning. It will relieve students and teachers from putting undue emphasis on merely learning/ teaching grammatical structures, and instead, will encourage them to use language in context which is the need of the hour to raise the proficiency level of adult EF learners.

This study was conducted with certain limitations. The study examined the beliefs of EFL grammar teachers and their students' perceptions using only quantitative measures. Addition of qualitative measures such as classroom observations and interviews could provide a better picture of teachers' practices and the perceptions underpinning these practices. Moreover, teachers' classroom practices may not necessarily reflect their beliefs about how grammar should be taught (Basturkmen, Loewen, \& Ellis, 2004); therefore, further investigation is needed to find out the factors medi- ating teachers' beliefs and classroom practices, and the paradoxes in the teachers' belief system.

\section{REFERENCES}

Aljohani, M. A. S. (2012). Grammar Beliefs of in-Service Teachers. British Journal of Arts and Social Sciences, 11(1), 96-108.

Al-Seghayer, K. (2011). English Teaching in Saudi Arabia: Status, Issues, and Challenges. Riyadh: Hala Print Co.

Assalahi, H. M. (2013). Why is the grammar-translation method still alive in the Arab world? Teachers' beliefs and its implications for EFL teacher education. Theory and Practice in Language Studies, 3(4), 589-599.

Alghanmi, B. \& Shukri, N. (2016). The relationship between teachers' beliefs of grammar instruction and classroom practices in the Saudi context. English Language Teaching, 9 (7), 70-86.

Basturkmen, H., Loewen, S. \& Ellis, R. (2004). Teachers' stated beliefs about incidental focus on form and their

classroom practices. Applied Linguistics, 25, 243-272.

Borg, S. (1998). Teachers' pedagogical systems and grammar teaching: A qualitative study. TESOL Quarterly, 32(1), 9-38.

Borg, S. (1999). Teachers' theories in grammar teaching. ELT Journal, 53(3), 157-167.

Borg, S. (2001). Self-perception and practice in teaching grammar. ELT Journal, 55, 21-29.

Borg, S. (2003). Teacher cognition in grammar teaching: A literature Review. Language Awareness, 12(2), 96-108.

Borg, S. (2006). Teacher cognition and language education: Research and practice. London: Continuum.

Borg, S. (2013). Teacher research in language teaching: A critical analysis. Cambridge, UK: Cambridge University Press.

Boroujeni, F. A. (2012). Investigating controversies in teaching grammar: A case for the Iranian high school.

Theory and Practice, 2(8), 1570-1575.

Brown, C. A., \& Cooney, T. J. (1982). Research on teacher education: A philosophical Orientation. Journal of

Research and Development in Education, 15(4), 13-18.

Burns, A. (1992). Teacher beliefs and their influence on classroom practice. Prospect, 7, 56-66.

Chowdhury, M. H. (2014). Teaching grammar in the English language classrooms in Saudi Universities. Express,

an International Journal of Multi-Disciplinary Research, 1(1), 1-9.

De Keyser, R. M. (1998). Beyond focus-on-form: Cognitive perspectives on learning and practicing second language grammar. In C. Doughty \& J Williams (eds.). Focus on form in classroom second language acquisition (pp. 4263). New York: Cambridge University Press.

Dörnyei, Z. (2007). Research Methods in Applied Linguistics: Quantitative, Qualitative and Mixed Methodologies. Oxford: Oxford University Press.

Ellis, R. (2006). Current issues in the teaching of grammar: An SLA perspective. TESOL Quarterly, 40, 83-107.

Estalkhi, N. N., Mohammadi, M., Bakshiri, N. \& Kamali, J. 
(2011). Gender differences among EFL teachers'beliefs and their classroom practice in Iranian context. Proceedings of INTED2011 Conference. 7-9 March 2011, Valencia, Spain.

Ezzi, N. A. A. (2012). Yemeni teachers' beliefs of grammar teaching and classroom practices. English Language

Teaching, 5(8), 170-184.

Grami, M. A. G. (2010). The Effects of Integrating Peer Feedback into University-Level ESL Writing Curriculum: A Comparative Study in a Saudi Context. PhD dissertation, Newcastle University.

Hos, R., \& Kekec, M. (2014). The mismatch between non-native English as a foreign language (EFL) teachers' grammar beliefs and classroom practices. Journal of Language Teaching and Research, 5(1), 80-87.

Javid, C. Z. (2014). Perceptive determination of Saudi EFL learners about the characteristics of an ideal English language teacher. Research on Humanities and Social Sciences, 4(8), 42-53.

Javid, C. Z., Farooq, U., \& Gulzar, M. A. (2012). Saudi English-major undergraduates and English Teachers'

perceptions regarding effective ELT in the KSA: A Comparative Study. European Journal of Scientific Research, 85(1), 55-70.

Johnson, K. E. (1994). The emerging beliefs and instructional practices of preservice English as a second language teachers. Teaching and Teacher Education, 10(4), 439-452.

Kagan, D. M. (1992). Implications of research on teacher belief. Educational Psychologist, 27(2), 65-90.

Kalsoom, T., \& Akhtar, M. (2013). Teaching Grammar: Relationship between teachers' beliefs and practices. Global Journal of Human Social Science Linguistics \& Education, 13(12), 54-61.

Khan, I. A. (2011). The Teacher of English: Pedagogic Relevance in Saudi Arabia. English Language Teaching, 4(2), 112-120.

Laufer, B. \& Girsai, N. (2008). Form-Focused instruction in second language vocabulary learning. Applied Linguistics, 29(4), 694-716.

Liton, H. A. (2012). Developing EFL teaching and learning practices in Saudi colleges: A review. International

Journal of Instruction, 5(2), 129-152.

Mohamed, N. (2006). An Exploratory Study of the Interplay between Teachers'Beliefs, Instructional Practices \&

Professional Development. $\mathrm{PhD}$ dissertation, The University of Auckland.

Moini, M. R. (2009). The impact of EFL teacher cognition on teaching foreign language grammar. Pazhuhesh-e-

Zabanha-ye Khareji, 49, 141-164.

Nishimruo, M., \& Borg, S. (2013). Teacher cognition and grammar teaching in a Japanese high school. JALT

Journal, 35(1), 29-50.

Pajares, M. F. (1992). Teachers' beliefs and educational research: Cleaning up a messy construct. Review of Educational Research, 62(3), 307-332.

Rahman, M., \& Alhaisoni, E. (2013). Teaching English in Saudi Arabia: Prospects and Challenges. Academic

Research International, 4(1), 112-118.

Richards, J. C. (1996). Teachers' maxims in language teaching. TESOL Quarterly, 30(2), 281-296.

Sheen, R. (2003). Focus on form-a myth in the making? ELT Journal, 57(3), 225-233.

Skehan, P. A. (1998). A cognitive approach to Language learning. Oxford: Oxford University Press.

Stokes, P. \& Wall, T. (2014). Research Methods. London: Palgrave

Underwood, P. R. (2012). Teacher beliefs and intentions regarding the instruction of English grammar under

national curriculum reforms: A theory of planned behavior perspective. Teaching and Teacher Education, 28, 911-925.

Ur, P. (1996). A course in language teaching. Cambridge, England: Cambridge University Press.

Uysal, H. H., \& Bardakci, M. (2014). Teacher beliefs and practices of grammar teaching: focusing on meaning, form, or forms? South African Journal of Education, 34(1), 1-16.

Wilhelm, K. H., \& Pei, B. C. (2008). University Teachers and Students' Perceptions of EFT Methodologies and their.

Effectiveness. GEMA Online Journal of Language Studies, $8(2), 79-102$.

Williams, M., \& Burden, R. (1997). Psychology for Language Teachers: a social constructivist approach. Cambridge: Cambridge University Press.

Woods, D. (1996). Teacher cognition in language teaching. Cambridge: Cambridge University Press. 